\title{
HOW SHE CAN SING
}

Here is this situation. Love.

The gravy, the cream. Something fatter

than silence. What is wrong with silence?

Anything else shakes the house.

The walls always go first

until even the lamp she uses for heat,

huddling underneath it until morning ... even that goes.

Yes, here is everything again. In order. In a package.

Yesterday, nothing, but now she finds

she is a body again.

She sweats to the dull ticking that enters her skin.

He is sudden. And pressing.

He notices everything. He arranges everything,

the cups fall into place, the scratchings inside the wall grow quiet. Before, she did not

have even herself. But how lucky:

here she is. Here he is. The face across from the face.

The eyes, noses, the mutual taste of breathing.

This could turn out to be the story with a beginning,

this might well be a year full of stories.

He is getting up from his chair, from his coffee, and even if he does not want to wait,

to see, to say he will be back-

he will be back.

Soon nothing but the back of his head disappearing.

Outside, nothing is clear. The sidewalks

are damp. It is early, the houses

are the same. She is safe. He is the back of a face.

His skin is the past. She stays.

She feels herself circling him wider and wider. She could

haul him in. She can let him go.

She looks at the window. It is her face. She closes it. 
This is her hand switching him off.

She has never needed this love.

She always saw how it would be.

She knew what he wanted. Looking back, she knows

how it will be. She enters it.

She sleeps. She always does. 